\title{
The Implications of Demonetization and Currency Constraints on Indian Tourism - A Perspective Analysis
}

\author{
Mary Jeniffer S, ${ }^{*}$ Anu Chandran ${ }^{\dagger}$ and Arnab Gantait ${ }^{\ddagger}$
}

\section{Abstract}

MSME's across the country which depends on cash transactions and not on electronic cash transactions bore the brunt of the demonetization policy declared on November 8, 2016. This study analyses the regulations which were originally enforced, then altered and reintroduced in a different format in a very short span of time has given rise to various undercurrents that affects tourism business. With respect to tourism, demonetization was a jolt as the policy decision came into force in the peak season, i.e., during the months of October-December when the tourist arrivals are usually high. Framed as a qualitative study in an exploratory mode adopting the Delphi Technique for deriving the inferences and apt deductions, this paper emphasizes the reviews of media reports for preparing the statements for the Panel configuring eminent tourism industry practitioners, academicians, consultants, NGO activists, and banking personnel. Further, an academic prediction regarding the nature and implications of the return to normalcy of tourism based on the assessment of the developments in the contemporary paradigm shift to the much proclaimed transparent economy. Also, the

* Pondicherry University, Puducherry, India; maryjeniffer21@gmail.com

† Pondicherry University, Puducherry, India; anoos_ind@yahoo.co.in

‡ Pondicherry University, Puducherry, India; arnab8376@gmail.com 
discrepancies involved in streamlining the denominations of currency notes are also discussed.

Keywords: Demonetization, Tourism Industry, Economic Impacts, Demand and Supply, Currency, Destination Image

\section{Introduction}

Demonetization has led to the sudden change in the pace of the pro-active functioning of various sectors in India. Following the devaluation of high denomination currency notes such as the Five Hundred Rupee notes and Thousand Rupee notes, tourism industry too experienced the 'demonetization nightmare.' The dramatic announcement left many in the lurch as it came as a jolt without adequate preparedness. As promised by the Government and the RBI, the sufferings faced by the citizens lessened as time progressed and a semblance of normalcy returned. However, it does not negate or offset the pains and trauma undergone by scores of people from all walks of life in the country. Unfortunately, subsequent the call of demonetization there were several suicides which were reported from various parts of India. Utter chaos all sectors and all sections of societies during the months of clouded November to January, part of India's peak tourism season. Owing to the fact that the ATM's were facing cash crunch and massive crowds were thronging the banks for exchanging the old currency notes, the influx to the premier tourist centers in the country dwindled in sync with the general moods of dissatisfaction and confusion that prevailed. There was a humongous hue and cry over the grit, tenacity, and stability of the decision of demonetization. Though it was portrayed as a powerful and path breaking move to curb terrorism and corruption and promote a cashless economy, the efficacy of the decision is still in question. The economic indicators lucidly projected a slowdown in the GDP growth. For a significant number of foreign tourists, the visit to India is a once in a lifetime activity. For them, the promise of change in the scenario is of no relevance as it does not really matter to them. What matters to them is the agony that the tourists experienced at that point of time. So, it is anybody's guess that the destination image and thereby the branding efforts of the Incredible India Campaign will 2 
take a beating. To add to the woes, the negative word-of-mouth would further mar the image and affect tourist arrivals. Reviews of certain media reports underpinned tourists' feelings about 'Athithi Devo Bhava' mainly as to whether the guests who had their footfalls in the destinations of India during demonetization were an unfortunate lot keeping in view the treatment they received with respect to cash transactions for tourism amenities and services. Due to currency ban, foreign tourists faced the hurdle and negative impacts that led to the hindrances of spending money, purchasing power, demand and supply of products, or hiring taxies (Economic Times, 2016). Now, months after demonetization, the claims made by the government such as demonetization stops funding of terrorism, resolves the problem of fake currency, makes the black money worthless, and reduce corruption (Ashish Kumar Tripathi, 2016) need to be verified thoroughly.

\section{Global Imprints of Demonetization}

There are multiple reasons for countries demonetizing their local units of currency. Some reasons are attributed to restrain terrorism, combat corruption, and to discourage a cash system. The process of demonetization involves either introducing new notes or coins of the same currency or completely replacing the old currency with new currency. The Coinage Act of 1873 or Mint Act of 1873 demonetized silver in favour of adopting gold standard as the legal tender of the United States. The withdrawal of silver from the economy resulted in a retrenchment of the money supply, which subsequently led to a five year economic depression in the country.

In the year 2002, demonetization occurred when the nations of the European Monetary Union adopted the Euro as its money value. In order to switch to the Euro, authorities first fixed exchange rates for the varied national currencies into Euros. With the introduction of Euro, the old national currencies were demonetized. However, the old currencies remained convertible into Euros for a while so that a smooth transition through demonetization was secured.

In November, 2016, the Indian government determined to demonetize the 500 and 1000 rupee notes, the two highest denomination notes in the country. These notes accounted for $86 \%$ 
of the country's cash supply. The government's rationale was that it will aid to eradicate counterfeit currency, fight tax evasion, and eliminate black money and money laundering and restrict terrorist financing activities. On 28 October 2016, the currency in circulation in India was 17.77 lakh crore (US\$260 billion). Indians travelling abroad and foreigners travelling to India for recreational, medical tourism or any other purpose were left holding a worthless paper in an alien land.

\section{Ramifications of Demonetization in Tourism Industry}

The implementation of demonetization had an impact almost all sectors. While the impacts on some of the sectors were negative there were others that had a positive turn of things. Unfortunately, the Tourism sector was one of the sectors that were negatively impacted. Domestic tourism post demonetization has drastically come down by $65 \%$ while international tourism inflow has reduced by $40 \%$ since November as compared to the previous year(The Hindu Business Line, 2016).Consumers have lost their confidence in tourism in the last two months of 2016. Tourism sector mainly gathers momentum around October to November and the devaluation of currency created road blocks to the promotional agenda. Moreover, there were several cancellations of bookings made during the peak season of tourism from November to January. There was a marked decline in booking of rooms and airlines tickets to almost $30-35 \%$ as compared to the preceding year. For tourist destinations beyond metros, businesses were down by as much as 40 percent. Tourism business in metros was forecasted to go down by 10 percent (The Economic Times, 2016). Cash shortage at airports and hotels became a nagging problem. Further, wayside amenities, home stays, agro-tourism ventures, entry points to national monuments, highway motels, and etc. that did not have card payment facilities faced the brunt of the policy decision. Western countries issued advisories in view of the cash crunch in India. Of the more than eight million foreign tourists who visited India last year, over 1.7 million arrived in the months of November and December, as per tourist arrival statistics (Times of India, 2016). 


\section{Demonetization in the Indian Context}

The French were the first to use the word Demonetize, in the years 1850 to 1855. Since then many countries have used the word and the policy with immense restrictions as well as discomfort, for it disrupts economics and also the population at large. In India, the first demonetization took place in 1946 and Rs 1000 and Rs 10,000 notes were demonetized. Later in 1978, Rs 1000, Rs 5000 and Rs 10,000 were demonetized. In 2016, the third demonetization replaced Rs 500 and Rs 1000 with new Rs 500 and Rs 2000 currency notes respectively. In January 1946, banknotes of Rs 1000 and Rs 10000 were withdrawn and new notes of 1000, 5000 and 10000 denominations were introduced in 1954. The Janata Party coalition government again demonetized banknotes of 1000, 5000 and 10000 rupees on 16 January 1978 as a means to curb counterfeit money and black money. Yet, unlike in 1946 and 1978, the present avatar of demonetization has taken place when India is fast emerging as one of the powerful economies of the world and a top rated tourism destination. The population of the country is also touching 1.25 billion and globalization has metamorphosed the business environments.

\section{Demonetization and Indian Tourism}

Demonetization has cast a shadow on the booming tourism and hospitality industries in India. The onset of the winter travel season has been thwarted by the unexpected hazards of demonetization. People have altered plans of overseas travel and instead are exploring various local tourist destinations. Demonetization with a cashless economy agenda and switch over to digitalization mode has affected the harmonious experiences of inbound and outbound tourists. Withdrawal of money from banks and ATMs was a hassle which is now lessening. The travel and hospitality industries are still facing a tough time. Many foreign trips sponsored by big brands and largely done through cash transactions are negatively affected with serious implication to tourism industry mainly due to the cash crunch. India's hospitality industry has been badly affected as hotel bookings lost a sizeable number of pay-in-cash only clientele due to demonetization. Approximately 60 percent 
drops in hotel bookings have been reported due to demonetization (The Hindu, 2016). The case of Foreign Tourists Hordes of foreign tourists in popular destinations such as Goa were ill prepared for Modi's shocking announcement as they did not possess bank accounts in India and were thus left stranded. Reports also suggest that foreign travellers are being coaxed into buying gifts and souvenirs in return for lower denomination notes and in some cases customers are being forced to make purchases of equivalent values (International Business Times, 2016). Many service providers in tourism made a good deal of business out of demonetization by offering to exchange the banned currency notes on a commission. Foreign tourists had to undergo the turmoil of paying for their basic requirements as food, accommodation and transportation as access to the new Rs 2000 and Rs 500 notes were not easily available. For tourists affected in areas such as Varanasi and Agra, the Uttar Pradesh Government immediately facilitated the exchange of old currency notes for the new legal tender (http://www.ibtimes.co.in/tourists-caught-demonetisation-mess703776).

\section{Cash Crunch and the Ordeals of Medical Tourism}

The cash crunch also posed a serious threat to medical tourism particularly among foreign tourists accompanying their ill friends and family seeking medical treatment requested doctors to postpone their surgeries and treatment due to demonetization. They provided with a fixed and tight budget, based on cash, those coming to seek medical treatments cancelled their trips while adding that they will only be willing to reconsider coming back if the situation gets resolved in a shorter span of time. Medical tourists were reported to lament over the conversion of currency in airport with its restrictive limits of exchange. The main challenge was to pay auto drivers, miscellaneous expenses and hospital charges from the point of arrival to departure meeting all the expenses incurred during the time of surgery (Afghanistan Medical Tourist). Demonetization has drastically hit medical tourism as neither the hospitals nor the government bodies chipped in seriously to support the foreign patients who were trapped unwittingly in the midst of a development of national concern. 
Iranian and Sudanese medical tourists were one of the majorly affected communities by the demonetization as they mostly do not have bank cards due to the permit restrictions in their countries. The scenario was same with the Cubans and Afghans who are argumentative about the currency exchange limit. Furthermore, the tourism industry faced a setback as the tourists who opted months ago in favour of visiting India as their winter destination cancelled travel plans due to the impacts of demonetization (The Hindu, 2016).

\section{The Aftermath - a Critique}

The tourism sector was extremely affected by the government decision to withdraw popular currency notes of high denomination values of Rs 500 and Rs 1000 currencies from the regular usage. It caused lot of strife to the foreign tourists during the processes post demonetization. Foreigners were trapped in the main destinations like Jaisalmer and Pushkar with shortage of currency, facing difficulty to pay for food and accommodation due to government restriction and limit of exchanging foreign currency. After demonetization, foreigners in the country were also exposed to severe liquidity problems. Most of the tourist spots came to a standstill when foreign money exchanges were forced to shut down their shops. Agencies providing foreign exchange and banks changing foreign currencies were also scant. This resulted in a $20 \%$ dip in the tourism business (Times of India, 2016). In the midst of demonetization, tourists from different parts of the world like Spain, France, and Israel were found stranded in different destinations. Meanwhile, the tourism businesses were also badly hit. A report quoting the Jaisalmer Tourist Association President Prithvi Raistated that a large number of rooms were unoccupied as many tourists have cancelled their bookings. Many travel agents faced a standstill in tourism business due to the cash crunch with current liquidity crisis. Tour operators stated that there has been an even worse decline of $50 \%$ dip in tourism business (Times of India, 2016). Tourism industry has a long way to recover from the demonetization effects which has to some extent tarnished the image. Recovery plans are afoot things have somewhat improved. Travel and hospitality sectors have to garner steam post 
demonetization. The full impact is yet to be assessed. Also, the implementation of new currency values of Rs 500 and Rs 2000 with an improper strategic plan has pushed the government to an entangled situation. The flow of cash in Indian economy is in the form of paper currency and not through plastic currency. Majority of the population in India use paper currency rather than plastic money, whereas digital currency or cyber cash is used for purchase by a very low percentage of people (Marzban Antia, TAAI President).

\section{Excerpts from Experts' Opinion - Thematic Analysis}

On Present and Future Dynamics - As per the data released, people were using Rs500 and Rs1000 rupee notes as the currency for major transactions (which amounted to $80 \%$ of all currency in circulation). The International Monetary Fund (IMF) avowed the parallel economy in India as $25 \%$, though the real percentage of it may be more than that. Less than $7 \%$ of the black money is in the form of liquid cash whereas others are in the form of assets. Black money has been infused into smaller banks and co-operative banks. $60 \%$ of the inventories are in unorganized places. Cashless transactions by adopting cyber cash, GST issues, high interstate transportation tax, are fiscal challenges before India at present National Tourism Policy should address and mitigate the outcomes of the above challenges on tourism industry. It must also streamline the flow of FDI. Adoption of customized technology can be the enabler of change for good.

- The Critical Perspectives - Almost 70 - 80percent of people lost their business due to demonetization in Andaman Islands. Most of them are petty shopkeepers and restaurant staff. Renowned Economists like Amartya Sen and Prabhat Patnaik had criticized the demonetization decision in that form. The estimations were proved wrong. For instance the expectation of 3.5 lakh crores to 4 lakh crores to be brought into the Indian economy. The bearing that the corporate have on Indian economy as per their business requirements questioned. Of course the accountants are benefited because there are several redundancies and discrepancies. 
- Impacts on Tourism - Demonetization affected tourism to such an extent that $65 \%$ hotel bookings were cancelled in between November-December, 2016 in various destinations. This period also witnessed a $45 \%$ drop in Foreign Tourist Arrivals (FTA's) and the GDP also stumbled. Though demonetization was a blow to the tourism industry, certainly the industry will rebound as things get better. The big toll demonetization has had on Indian tourism is hopefully a short one as the players who are in various tourism and hospitality sectors shall show their mettle. Tourists' spending in the present have notably reduced. We are yet to see if demonetization was able to stem the black money. The struggles faced by tourists will definitely play spoilsport with the branding exercises. The PR of the country will have to work overtime to transform the image. The small travel companies which had to pull the shutters could always return and expect great results in prospect.

\section{On Government's Role}

Government intervention could be in the direction enlisted below for desirable results:

- Change and streamline the tax structure

- Provide incentives and liberalize loans and grants to tourism and hospitality sectors.

- Instil confidence in foreign and domestic tourists by ensuring hassle free withdrawal of money and also cash availability in the requisite denominations.

- Digitized format of cash transaction can wait till the preparations are foolproof and complete.

(The participants of Delphi Analysis represented the banking industry, travel companies, hotel sector, tourism academia and Public Sector Tourism Corporation. The panel comprised of $\mathrm{Mr}$. Prem Subramaniam - Former Advisor Tourism Infrastructure Development Finance Company (IDFC), Dr. D. Thomas Franco Rajendra 
Dev - Senior Vice President All India Bank Officers Confederation; Chennai, Mr. Naresh Mehta - Proprietor, Mehta Travels,Puducherry, Mr. Tamilselvam - Chief Executive Officer, World Travel Club, Chennai, Mr. D. Lawrence Sagayaraj - General Manager, Anandha Inn, Puducherry, Mr. D. Lawrence Sagayaraj - General Manager Anandha Inn, Puducherry, Mr. Chinnam Reddy - Director, National Institute of Tourism \& Hospitality Management, Hyderabad, Mr. Gopalakrishnan Proprietor, Pondicherry Tours, Puducherry).

\section{Inferences and Implications}

- In India, demonetization had its effect on various sectors with a sizeable magnitude of cash transactions such as real estate, construction, jewellery, high-end retail, white goods along with travel and tourism. They were adversely affected.

- In the long term, it is expected that the economy will benefit from the reduction of black money, which will lead to higher tax collection, better business environment, less corruption and cash transparency.

- World Bank perceives a lower growth rate for India but maintains, that India will continue to remain the world's fastest growing economy ahead of China, in 2017. It has lowered GDP estimates for India from $7.6 \%$ to $7 \%$ for FY 17 18. But anticipate India's growth to pick up again in FY 18 19 with several reform measures including GST and insolvency and bankruptcy code.

- Hotel, trade, transport and communication sectors are expected to witness a sharp decline in Gross Value Added from 9.0 in FY $15-16$ to $6.0 \%$ in FY 16-17.

- In India, the peak tourism season is from October to January. While most of the domestic travellers visit Rajasthan, Maharashtra, Gujarat and Karnataka in October and November, scores of pilgrims visit shrines such as Sabarimala in December. The year-end party seekers look forward to a break in Goa and Maharashtra during late December and early January. Most of these tourist 
destinations have seen a drastic reduction in bookings in 2016.

- According to a recent study by the Associated Chambers of Commerce \& Industry of India (Assocham), there has been a 65 percent drop in Christmas and New Year seasonal bookings in 2016. Tourists who spend their vacation in Uttarakhand, Madhya Pradesh and Kerala have decided to stay back instead of taking their annual break due to demonetization. With demonetization most of the countries' travel advisories issued cautioned travellers who wanted to travel to India. It has led to a dip in the international travel to India in a decline stage with a drop of 45 percent. The months of November to January normally witness the maximum inflow of international tourists to India. Cash crunch has adversely affected the liquidity of currency exchanges in the country leading to such a difficult situation.

- Demonetization disrupted the travel plans of inbound and outbound tourists along with a lot of restriction for domestic travellers. Wedding plans got cancelled which led to the decline of travel for honeymoon packages and wedding tourism.

- Demonetization has created newer problems, though it was a courageous move to immediately kill the flow of black money in the country. The foreign and domestic tourists who were carrying high-value currency with them for their expenses had no way to go to the banks to get them exchanged for the new currency and had a tough time trying to solve the issue.

- Post demonetization, the tourism sector has started the foray into the digital travel booking mode. There has been a surge in mobile transactions in this sector too. Smartphone prices have come down crashing in India. This has led to a rapid mobile penetration in the Indian market. This has led the Indian consumers to a growing use of mobile devices to book travel. Leading online travel portals are indicating 
that the bulk of the hotel bookings are being done through websites and mobile apps.

- The travel and hospitality industry accentuated the use of plastic money post demonetization. Survey done by a leading online travel web portal indicated the inclinations of Indian travellers to use credit or debit card over cash. More than 37\% travellers chose plastic money over cash for making bookings and travelling. It is also an optimistic sign in case of online hotel bookings as there has been a double digit growth and the same is expected throughout most of 2017.

- Post demonetization, Indian government has taken serious action plans to curb the negative impacts upon foreign tourists arrivals after November 8, 2016. Archaeological Survey of India (ASI) efficiently transitioned to the cashless mode of payment by simplifying the process of e-tickets. It little bit spruced-up the growth rate of Foreign Tourists Arrival (FTA) by $9.3 \%$ in comparison of 2015 to 2016. The most notable part is an extensive growth of e-tickets sold during $09 / 11 / 2016$ to $08 / 12 / 2016$ which increased to 28,176 from 2,807 during 09/10/2016 to 08/11/2016 with a consequent amount of Rs 181.49 lakh and Rs 3.10 lakh correspondingly.

\section{Conclusion}

Demonetization in the current dimensions is mooted to be the biggest reform move in India since the nationalization of fourteen private banks in 1969. There was a major overhaul in the systemic aspects of leading industries including tourism and hospitality. The GDP forecasted for January, 2017 in the earlier scheme of things was $7.6 \%$ where in the current estimate project it as hovering around $7.1 \%$. Indian economy suffered a setback which is portrayed as a small time affair though demonetization caused certain devastation to the progression of tourism in many premier destinations. The key question raised by many expert panellists who participated in the Delphi Analysis was if it is correct to 
stranglehold a burgeoning industry like tourism which is already viewed as a fragile industry, extremely sensitive, to external events. The experts stated that economic instability is always a deterrent for the future of tourism and expected the Government to lift the restrictive measures completely at the earliest. If demonetization can bring forth positive changes in future as highlighted, there is lot better in store for tourism as well. The travel advisories issued by countries like Canada (which has advised caution to its citizens travelling to India) hopefully will not have a long lasting effect on their outbound tourists to India. Many countries asked their citizens to make sure whether their credit and debit cards will work in India. It is time for the Indian government to start the image building exercise. The next few months will unravel the real effects of demonetization, whether positive or negative. Many are skeptical about achieving the real aim of uprooting black money. The cashless economy as of now is somewhat at a distance. The adoption of cashless transactions needs to be implemented at a time when the citizens of the country are absolutely geared up.

\section{References}

Chairman. CBDT. (2012). Measures to Tackle Black Money in India and Abroad, Parts I \& II. Ministry of Finance. Government of India.

Deodhar, R. P. (2016). Black Money and Demonetisation. Browser Download This Paper.

Tripathi, A. K. (2016). Demonetization - Challenges for Rural India. International Journal of Higher Education Research \& Development. ISSN: 2456-2629

\section{Websites}

Demonetisation has hit arrival of tourists. Retrieved February 14, 2017, from http://www.thehindu.com/news/ national/ \%E2\%80\%98 Demonetisation-has-hit-arrival-of-tourists\%E2\%80\%99/ article16907649.ecehttp:// pib.nic.in/newsite/PrintRelease.aspx?relid $=155942$

Demonetisation impact on various sectors: Government needs to inject positive sentiment, led by tax cuts. (2016, December 07). Retrieved December 08, 2016, from http://economictimes.indiatimes.com/ 
news/ economy/ indicators/ demonetisation-impact-on-varioussectors-govt-needs-to-inject-positive-sentiment-led-by-taxcuts/articleshow/55843771.cms

Demonetisation: Cash crunch hits travel and tourism sector hard. (2016, December 27). Retrieved January 01, 2017, from http:// www.firstpost.com/business/demonetisation-countdown-to-day-50travel-and-tourism-sector-affected-due-to-cash-crunch-pay-in-cashpolicy-in-hotels-3173974.html

Demonetisation: Tourism industry knocks at government doors with bag of woes. Retrieved December 09, 2016, from http:// economictimes.indiatimes.com/articleshow/55465914.cms?utm_sourc $\mathrm{e}=$ contentofinterest\&utm_medium $=$ text\&utm_campaign $=$ cppst

Demonetization. (2017, June 20). Retrieved June 21, 2017, from http:/ / www.investopedia.com/terms/d/demonetization.asp\#ixzz4Y 4Psebm1 http://www.mapsofindia.com/my-india/government/ two-months-after-demonetisation-an-indian-economy-snapshot

Fry, E. (2016, December 26). How India Broke Its Economy (on Purpose). Retrieved January 05, 2017, from http://fortune.com/ 2016/ 12/ 26/ india-demonetization-rupee-notes /

Has Demonetization Really Changed Travel Trend in India? (2017, January 12). Retrieved February 14, 2017, from http:// www.hotelcoraldigha.com/demonetization-really-changed-traveltrend-india/

Impact-of-demonetization-on-indian-tourism. Retrieved January 02, 2017, from https://rmoneyindia.com/research/equity/Impact-ofDemonetization -on-Indian-Tourism

Lulla, A. B. (2016, November 28). Indian Startups, Entrepreneurs, Founders, Stories, Startups, Resources, Research, Business Ideas, Product and App Reviews, Small Business. Retrieved December 01, 2016, from https://yourstory.com/2016/11/demonetisation-medicaltourism/-tourists \% E2\%80\%99/article16907649.ece

Rathi, P. (2016, November 13). Tourists caught in demonetisation mess. Retrieved December 01, 2016, from http://www.ibtimes.co.in/ tourists-caught-demonetisation-mess-703776

What is the history of demonetization of Indian Currency? Retrieved January 13, 2017, from https:/ / www.quora.com/What-is-the-historyof-demonetization-of-Indian-Currency 